\title{
The Reform and Practice of the Practical Teaching System of Marketing Major in Application-Oriented Universities
}

\author{
Liang Chenglei \\ Dongfang College \\ ShanDong University of Finance and Economics \\ Taian, China 271000 \\ liangchenglei@163.com
}

\begin{abstract}
There is not a perfect practical teaching system in marketing major in many application-oriented universities, which leads to the difficulty in realizing the goals of talents training. Based on the characteristics of applied talents training mode and the requirement of marketing major, this paper analyzes the existing problems in practical teaching, and constructs a practical teaching system which is suitable for the marketing major of application-oriented universities: to clear orientation of talent training, to optimize practical teaching content, to encourage students to carry out practical activities, to strengthen the construction of training base and double-qualified teachers. This paper insists on the combination of theory and practice, which avoids the limitation of pure theoretical model.
\end{abstract}

Keywords-application-oriented universities; marketing major; practical teaching system; orientation of talent training

\section{INTRODUCTION}

In recent years, with China's steady economic growth and economic globalization, the society needs a large number of high-level professionals in the undergraduate level of marketing professionals.

But many universities often pay attention to the training of theoretical knowledge, ignoring the cultivation of professional skills and application ability, so that graduates can't meet the actual needs of the work, the phenomenon of "difficult employment" has emerged. Facing the world economic integration and the increasingly fierce market competition, the school must face up to the problems existing in the talents training, to further improve the practical teaching system, in order to cultivate applied marketing talents to meet the needs of the society.

\section{Analysis on the Problem of the Professional} Practical TEACHING System OF THE MARKETING MaJor OF THE APPLICATION-ORIENTED UNIVERSITIES IN CHINA

The traditional practical teaching content has played a very important role in the long-term educational practice process. But for a long time, many colleges and universities hold a wrong idea of education: colleges and universities should take the theoretical teaching as the main, and take the practical teaching as the assistant, practical teaching is only a part of theoretical teaching, failed to realize the value of practical teaching. Along with the social progress and the development of higher education, the reform of traditional education is the trend of future development ${ }^{[1]}$.

Through the collection of relevant data, the practical teaching system of marketing major exists the following problems:

\section{A. Not Clear in the Orientation of Talents Training Target}

The development of society not only needs a certain number of theoretical talents, but also needs a large number of practical talents in practical positions. From the construction of school discipline, teacher's ability, the quality of students, teaching level and school tradition and so on, it is difficult to cultivate talents of top-notch level theory for the marketing major in application-oriented universities. The orientation of marketing major in application-oriented universities should be to train the applied talents.

Now many application-oriented universities do not investigate social demand for marketing personnel's quality, the orientation of talents training is not clear, this will have a negative impact on the allocation of teaching resources, the construction of the teaching staff, the selection of teaching content and methods, the development of teaching activities and so on.

And the professional training objectives in marketing major of universities are basically the same, did not really reflect the characteristics of the application-oriented undergraduate, the style of the training of talent is basically the same.

\section{B. Lack of System Construction of Practical Teaching System}

Many application-oriented universities are not in accordance with its own characteristics to construct practical teaching system in marketing major in the course of teaching, generally used to impart theoretical knowledge in the classroom, pay attention to theoretical teaching and neglecting practical teaching ${ }^{[2]}$.

For example: the total number of theoretical teaching hours is too large, the number of practical teaching hours is relatively small; practical teaching system is incomplete, the specialized practical teaching planning, management, research and evaluation mechanism is absent; the experiment course is 
completely dependent on the theory curriculum, without system, and lacks the coherence of the practical teaching system. The mode of practical teaching training is not scientific.

And the practical teaching and the actual activities have little contact. Most of these practical activities are carried out on campus, the combination of teaching content and practical work is ignored. The students' practical innovation ability and operational skills are poor and is not popular with enterprise.

\section{Old Content, Single Method in the Practical Teaching}

First of all, the content of the practical teaching is old, and the update slows, cannot meet the needs of the society for the application -oriented talents. The practical content is quite old, and many are arranged after theoretical teaching, it is difficult to adapt to the economic development ${ }^{[3]}$.

Secondly, the method of practical teaching is little, and teaching methods can't be innovative. Traditional experimental teaching procedures are usually same: students enter the lab at the specified time, operate according to the prescribed procedures after waiting for the teacher to explain, then the experimental results is obtained, it is difficult to exert students' subjective initiative, and there is no creative education and personalized education.

\section{Limited Resources, Lack of Professional Construction}

Due to the limited educational resources, these institutions have less investment in marketing professional, in practical teaching management also lack incentive mechanism, can't fully stimulate the enthusiasm of teachers. Both the construction of training base and the teachers are not perfect, this seriously restricts the development of professional practical teaching.

So we can know that the practical teaching system of marketing major in application-oriented Universities has a certain gap between the theoretical expectation and the reality. Practical teaching is an important aspect of marketing professional education in application-oriented universities, which is different from other education.

On the realistic level, the development of the characteristic also has no solid foundation to do the support. Therefore, it is necessary to construct a practical teaching system which conforms to the marketing major of the application- oriented universities, which is the objective requirement of perfecting the practical teaching of the education and the realistic requirement of strengthening its connotation construction.

\section{Construction of Practical Teaching System of the MARKETING MAJOR OF THE APPLICATION-ORIENTED UNIVERSITIES IN CHINA}

\section{A. Clear Orientation of Talent Training}

The application-oriented universities should update the concept, completely abandon the traditional concept, and put the practical teaching in the same important position as the theoretical teaching. Both of them play an important role in the cultivation of applied talents. To deal with the relationship between theoretical teaching and practical teaching from the aspects of educational thoughts, teaching contents and teaching methods. Schools need to realize that only theoretical teaching and practical teaching have been carried out, the teaching quality marketing major in application-oriented universities can be guaranteed, the objectives of talent training can be achieved.

The orientation of talents training target is: meet the demand of society and economy, meet the demand of local development, work in marketing management at the grass-roots level, cultivate all-round development, have good humanistic literacy and solid professional knowledge. Not only has certain foundation of marketing theory and ability of practical operation, but also can reflect the applied characteristic ${ }^{4]}$.

\section{B. Optimizing Practical Teaching Content, Encourage Students to Carry Out Practical Activities}

Compressing Students' Compulsory Courses, increase class hours of elective courses and practical courses.

Under the premise of not affecting the teaching quality of the professional theory course, increase the class hours of practical curriculum. Focus on its own characteristics, pay attention to the development of practical courses. Increase the proportion of elective courses, can fully mobilize the enthusiasm of students to learn and improve students' learning efficiency.

The school encourages students to participate in practical activities, such as disciplinary competitions, campus cultural practices, creative activities or social practices.

Those who meet the relevant provisions of the school can be awarded innovative credits. Schools encourage students to actively obtain various types of certificates, and to improve their competitiveness of employment ${ }^{[5]}$.

\section{Strengthen the Construction of the Training Base}

Training base is an important place for practical teaching, which is related to the quality of students' training. Schools should increase investment in training base within the school; schools should actively look for enterprises to carry out schoolenterprise cooperation in order to improve the students' practical ability.

The construction of the campus training base needs great investment, in the beginning of the construction schools should do a good job overall planning, have a reasonable layout, and timely expand or update. Should form their own characteristics, schools and local economic development should be closely integrated. It is helpful to cultivate the core competence of the students, which is the core competitiveness of the students in the employment market to get a dominant position.

Off-campus training base is an important part of the practical teaching system. In off-campus training base, students can learn more about the operation of the business process, compared to the school to learn more specific and practical, It is more beneficial to develop their professional skills and operational skills. Universities should deepen the schoolenterprise cooperation; expand the width and depth of schoolenterprise cooperation. Continue to seek more partners, and to discuss further cooperation, in order to form a deeper and closer relation of cooperation $^{[1]}$.

Establish a good management system of school-enterprise cooperation to ensure standardization of university-enterprise 
cooperation. In this process, the school must be closely linked with the enterprise, enterprises who should be more experienced practitioners as external training instructor, the school should also send a special instructor to go to the enterprise, so that students can receive dual management.

\section{The Construction of Double-qualified Teachers}

The so-called "double master" teachers, that is, both with the teaching theory of knowledge of the teachers, but also with the ability to practice.

On the one hand, universities may require teachers to actively participate in more research projects to improve the theoretical quality. On the other hand, with the method of "please come in, send out".

Teachers are encouraged to participate in various academic conferences, expert forums, professional societies or industry associations, are supported to go out and participate in business $\operatorname{practice}^{[6]}$.

At the same time, establish a team of part-time teachers, who selected from the community. From the relevant enterprises and institutions to employ the marketing professionals as part-time teachers who have a wealth of practical experience and teaching ability. To strengthen the students on the new technologies, new knowledge of marketing, and make them familiar with the requirements of social marketing personnel.

Through the school teachers and outside experts combined, so that the training objectives of marketing major in the application- oriented universities can be achieved.

The sustainable development of the society needs a number of practical talents with the ability to face the problem, the ability to solve practical problems. The goal of marketing major in the application-oriented universities is to cultivate practical talents with strong practical ability, the cultivation of practical ability training needs a scientific and reasonable system of practical teaching. This paper puts forward some suggestions from four aspects, such as training goal, training content, training base and teachers, so as to provide useful help for the problems to be solved ${ }^{[3]}$.

\section{CONCLUSION}

Economic globalization, the widespread use of the Internet, the promotion of network marketing makes the rapid development of marketing theory and practice, also makes the content of marketing more abundant, these changes put forward higher requirements to the practical teaching content, practical ways and methods of marketing major. Applicationoriented universities need to further develop its own characteristics, so students can enjoy the higher quality education in marketing major. Therefore, it is necessary to construct a practical teaching system which is suitable for students' characteristics, to form their own academic advantages and characteristics of running a school, to strengthen the construction of double-qualified teachers and practical base, can truly to cultivate the comprehensive ability and the high quality marketing talents that the society needs.

\section{REFERENCES}

[1] Maskell B. "Performance measurement for world class manufacturing"[J].Corporate Controller, 1992(1): pp.44-48.

[2] Williamsj. "Professional Leadership in Schools"[M]. London: Kogan Page Ltd, 2002, pp.7.

[3] Guo-ying Wu. "Research on the Construction of Practicing Teaching System in Humanistic Disciplines of Higher Learning Institutions ---Based on Marketing Philosophy"[D]. Doctoral Dissertation of Tianjin University, 2010, pp.46-52.

[4] Jing Liu. "The practical teaching research of the new local colleges"[D]. Master Thesis of JiangXi Normal University,2012, pp.27-32.

[5] Xin Zhen. "The study of the application-oriented talent training mode of undergraduate education in marketing major"[D].Master Thesis of GuiZhou Normal University, 2009, pp.41-47.

[6] Taylor, B. "Strategic Indicators for Higher Education Improving Performance "[M]. Princeton: Peterson's Guides. 1993, pp.24-26. 